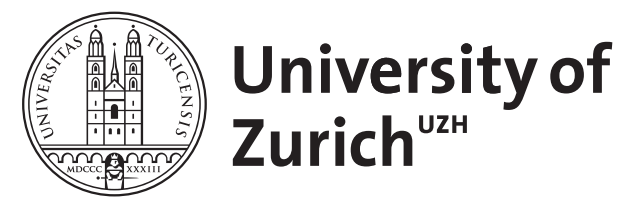

\title{
Potassium channels in epithelial transport
}

\author{
Warth, Richard
}

\begin{abstract}
Epithelial cells in the kidney, gastrointestinal tract and exocrine glands are engaged in vectorial transport of salt and nutrients. In these tissues, $\mathrm{K}+$ channels play an important role for the stabilization of membrane voltage and maintenance of the driving force for electrogenic transport. Luminal $\mathrm{K}+$ channels represent an exit pathway for the excretion of $\mathrm{K}+$ in secreted fluid, urine and faeces, thereby effecting body $\mathrm{K}+$ homeostasis. Indeed, the expression and function of several luminal $\mathrm{K}+$ channels is modulated by hormones regulating water, $\mathrm{Na}+$, and $\mathrm{K}+$ metabolism. In addition to net transport of $\mathrm{K}+$ in the serosal (or apical) direction, $\mathrm{K}+$ channels can be coupled functionally to $\mathrm{K}+$-transporting ATPases such as the basolateral $\mathrm{Na}+/ \mathrm{K}+$ ATPase or the luminal $\mathrm{H}+/ \mathrm{K}+$ ATPase. These ATPases export $\mathrm{Na}+\mathrm{or} \mathrm{H}+$ and take up $\mathrm{K}+$, which is then recycled via $\mathrm{K}+$ channels. This review gives a short overview on the molecular identity of epithelial $\mathrm{K}+$ channels and summarizes the different mechanisms of $\mathrm{K}+$ channel function during transport in epithelial cells
\end{abstract}

DOI: https://doi.org/10.1007/s00424-003-1075-2

Posted at the Zurich Open Repository and Archive, University of Zurich

ZORA URL: https://doi.org/10.5167/uzh-156261

Journal Article

Published Version

Originally published at:

Warth, Richard (2003). Potassium channels in epithelial transport. Pflügers Archiv : European Journal of Physiology, 446(5):505-513.

DOI: https://doi.org/10.1007/s00424-003-1075-2 


\section{Richard Warth \\ Potassium channels in epithelial transport}

Received: 4 March 2003 / Accepted: 26 March 2003 / Published online: 18 April 2003

(C) Springer-Verlag 2003

\begin{abstract}
Epithelial cells in the kidney, gastrointestinal tract and exocrine glands are engaged in vectorial transport of salt and nutrients. In these tissues, $\mathrm{K}^{+}$ channels play an important role for the stabilization of membrane voltage and maintenance of the driving force for electrogenic transport. Luminal $\mathrm{K}^{+}$channels represent an exit pathway for the excretion of $\mathrm{K}^{+}$in secreted fluid, urine and faeces, thereby effecting body $\mathrm{K}^{+}$homeostasis. Indeed, the expression and function of several luminal $\mathrm{K}^{+}$ channels is modulated by hormones regulating water, $\mathrm{Na}^{+}$, and $\mathrm{K}^{+}$metabolism. In addition to net transport of $\mathrm{K}^{+}$ in the serosal (or apical) direction, $\mathrm{K}^{+}$channels can be coupled functionally to $\mathrm{K}^{+}$-transporting ATPases such as the basolateral $\mathrm{Na}^{+} / \mathrm{K}^{+}$ATPase or the luminal $\mathrm{H}^{+} / \mathrm{K}^{+}$ ATPase. These ATPases export $\mathrm{Na}^{+}$or $\mathrm{H}^{+}$and take up $\mathrm{K}^{+}$, which is then recycled via $\mathrm{K}^{+}$channels. This review gives a short overview on the molecular identity of epithelial $\mathrm{K}^{+}$channels and summarizes the different mechanisms of $\mathrm{K}^{+}$channel function during transport in epithelial cells.
\end{abstract}

Keywords $\mathrm{K}^{+}$channel $\cdot$ Potassium $\cdot$ Reabsorption . Secretion · Intestine $\cdot$ Kidney

\section{Introduction}

Transport of solutes, electrolytes and water across epithelia cells is essential for homeostasis of salt and water metabolism, reabsorption of nutrients, exocrine secretion and excretion of metabolic end-products. In epithelia, $\mathrm{K}^{+}$channels are involved in different cellular functions: (1) maintenance of a polarized cell membrane as a driving force for electrogenic transport; (2) cell volume regulation; (3) $\mathrm{K}^{+}$excretion according to meta-

\section{R. Warth ( $)$}

Physiologisches Institut,

Winterthurerstrasse 190, 8057 Zürich, Switzerland

e-mail: warthri@physiol.unizh.ch

Tel.: +41-163-55046

Fax: +41-163-56814 bolic needs; (4) $\mathrm{K}^{+}$recycling across luminal and basolateral membranes (functionally coupled to $\mathrm{K}^{+}$-exchanging ion pumps); (5) cell fate: differentiation versus proliferation or apoptosis.

In the human genome around 80 different genes for $\mathrm{K}^{+}$ channel $\alpha$ - and $\beta$-subunits have been described (http:// www.gene.ucl.ac.uk/nomenclature/genefamily/

KCN.shtml). In addition, hetero-oligomerization and splice variants yield a large number of structurally and functionally different native $\mathrm{K}^{+}$channels. Table 1 gives an, inevitably incomplete, overview of the epithelial expression of different $\mathrm{K}^{+}$channel genes. In recent years, the breathtaking progress of protein analysis and gene discovery has sped up our understanding of for $\mathrm{K}^{+}$ channel structure and the role of these channels in genetically determined diseases. However, our knowledge of the tissue-specific expression pattern and its consequences for the function of native epithelia is still far from complete. The combination of molecular and biochemical techniques, genetically modified animals and functional methods will help to gain more insights into the diversity of epithelial $\mathrm{K}^{+}$channel physiology.

\section{Basolateral epithelial $\mathrm{K}^{+}$channels: driving force and cell volume regulation}

In polarized epithelial cells basolateral $\mathrm{K}^{+}$channels hyperpolarize the cell membrane, thereby increasing the driving force for other electrogenic transport systems. Depending on the paracellular resistance, basolateral hyperpolarization leads also to hyperpolarization of the luminal membrane supporting transport across the luminal membrane. In epithelial cells from rat colonic crypts two distinct basolateral $\mathrm{K}^{+}$channels have been identified at the molecular level, exemplifying the physiological role of basolateral $\mathrm{K}^{+}$channels in general. Resting voltage of rat colonic enterocytes is mainly determined by KCNN4 (IK1, SK4 [17, 18, 40, 42, 65, 107]), a $\mathrm{K}^{+}$ channel with a 10 - to 20 -pS single-channel conductance (Fig. 1C). KCNN4 bound to calmodulin [21, 43] is 


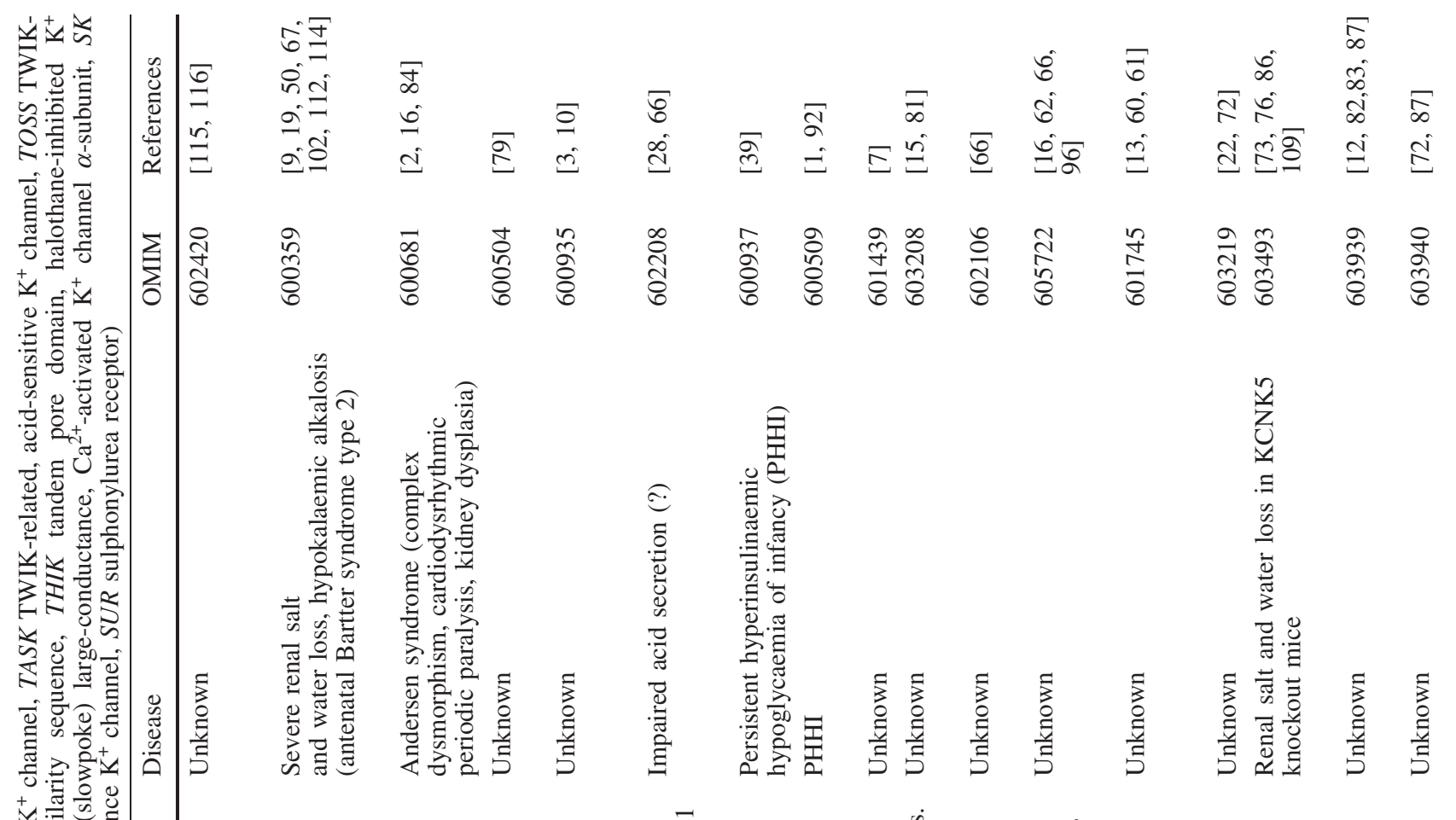

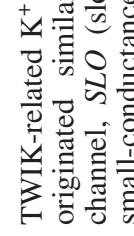

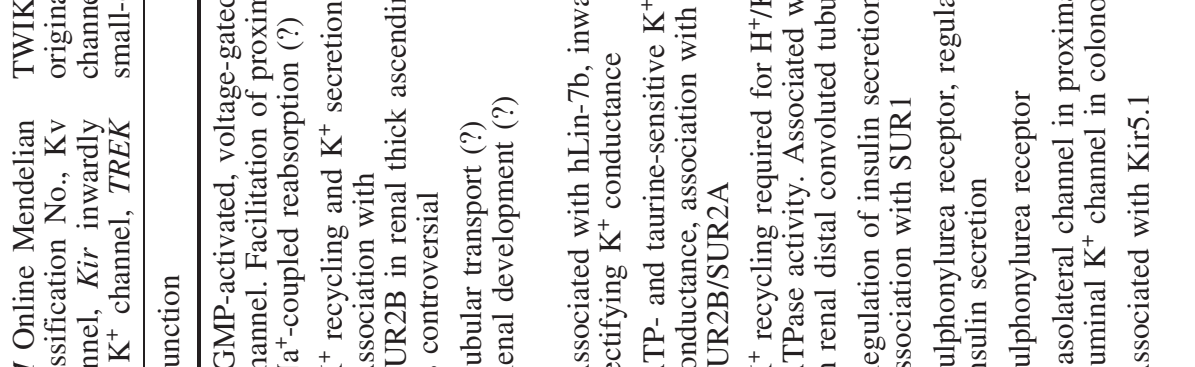

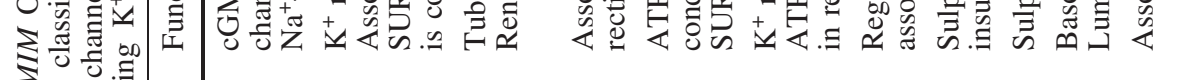

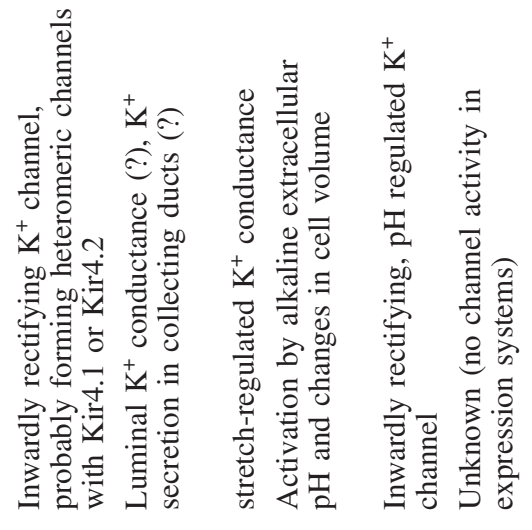

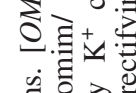

官言空:

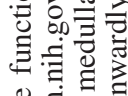

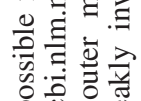

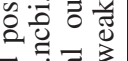

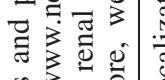

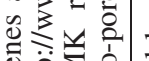

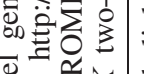

త

空语

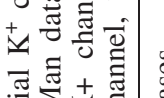

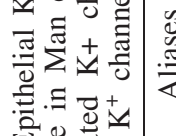

뇌유

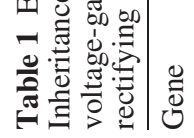

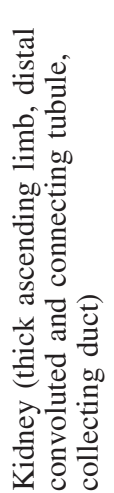

包

苞

है

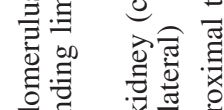

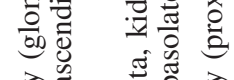

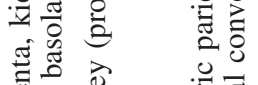

离苛

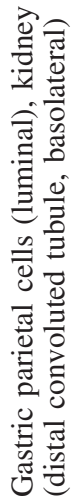

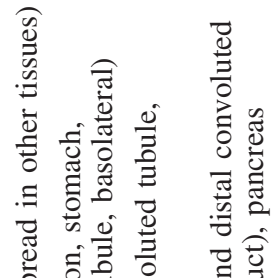

离

营

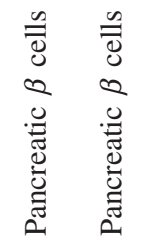

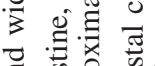

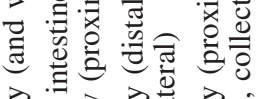

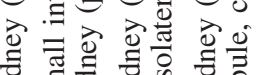

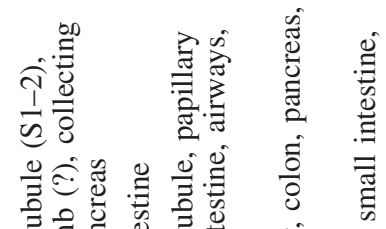

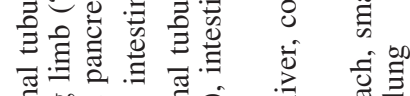

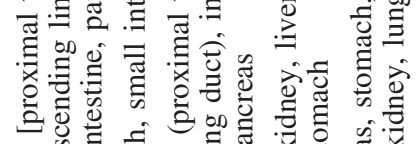

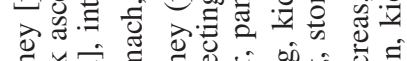

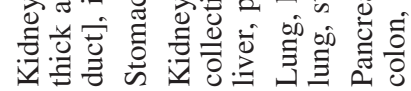




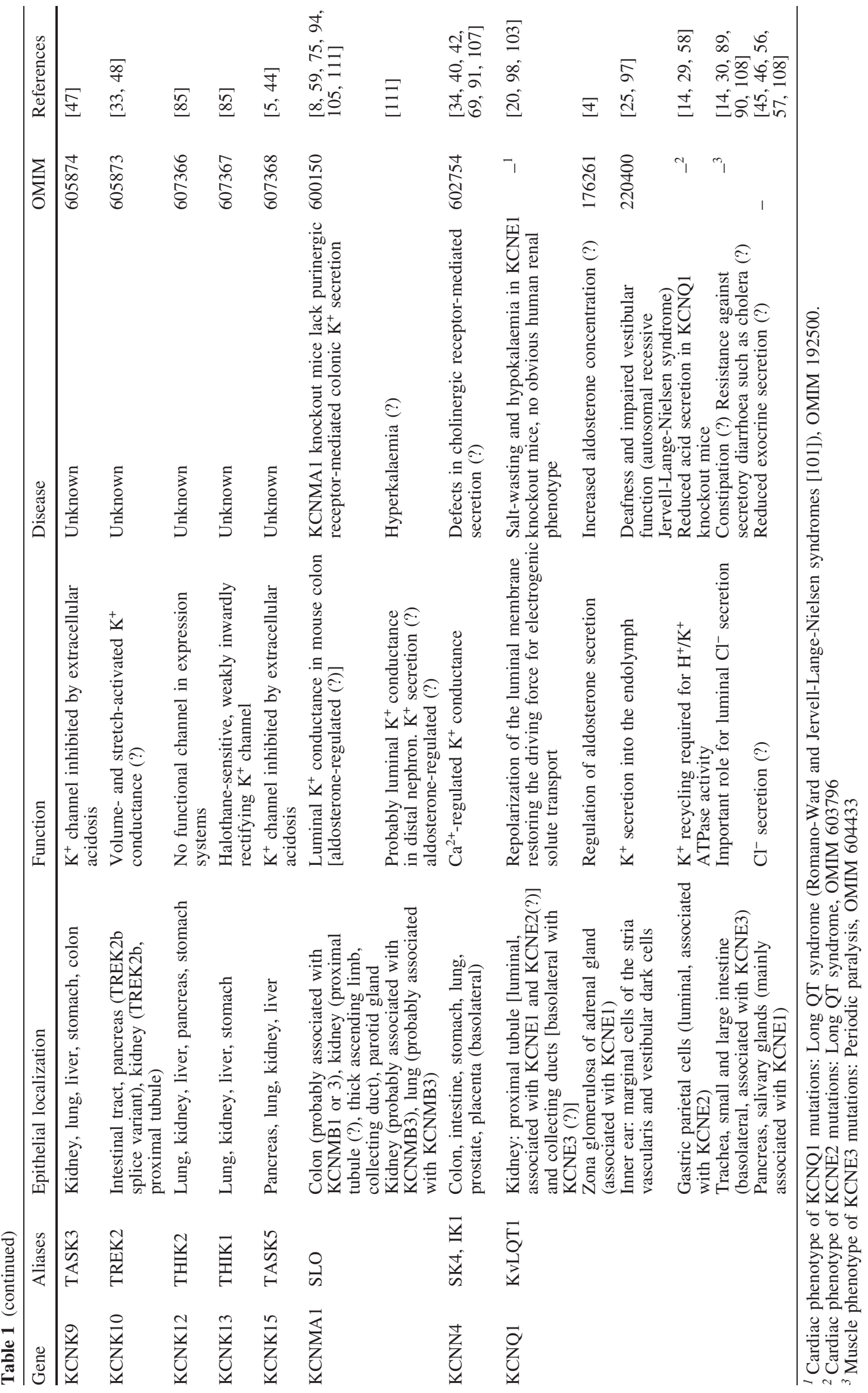


A

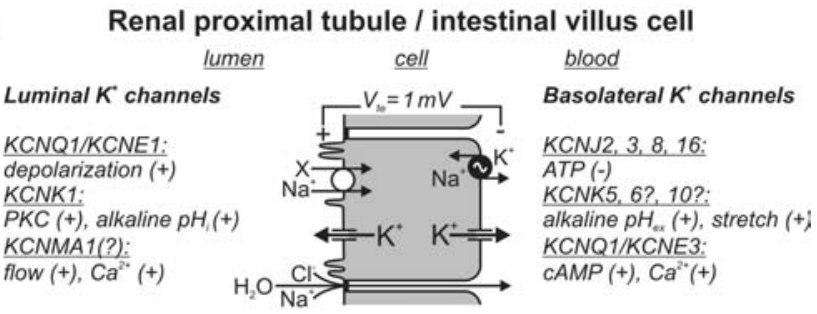

B

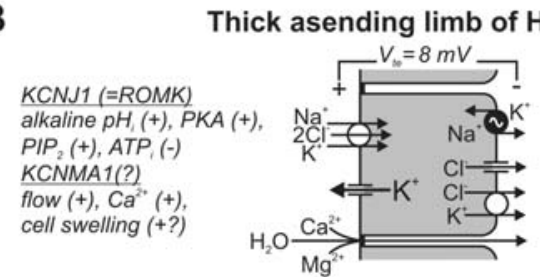

C

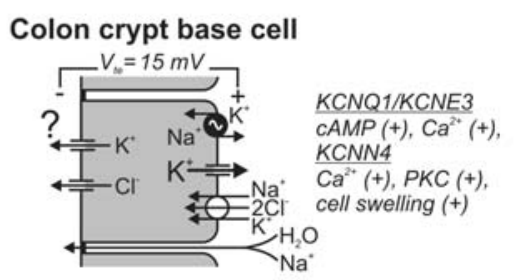

D

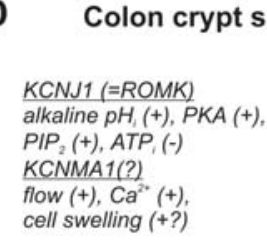

E

KCNE2/KCNQ1 acidic $p H_{e x}(+), c A M P(+)$. $\mathrm{Ca}^{2 *}(+)$ KCNJ10 acid resistent

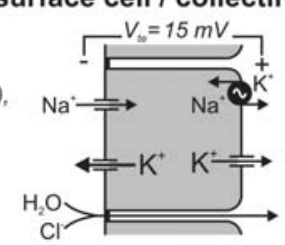

\section{KCNQ1/KCNE3} CAMP (+), $\mathrm{Ca}^{2+}(+)$, KCNN4 $\mathrm{Ca}^{2 *}(+), P K C(+)$, cell swelling $(+)$

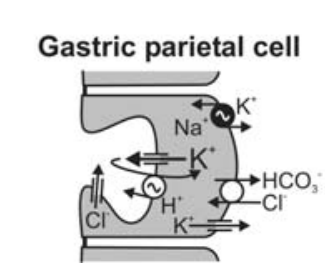

Fig. 1A-E Simplified models for $\mathrm{K}^{+}$channel function in different cell types. For simplicity, only one $\mathrm{K}^{+}$channel is drawn on basolateral or luminal side, although several different channels might be present. $\mathrm{K}^{+}$channel genes are named according to the Human Genome Organization (HUGO, http://www.gene.ucl.ac.uk/ nomenclature/genefamily/KCN.shtml). Main regulation of $\mathrm{K}^{+}$ channels is indicated as $(+)$ for stimulation and $(-)$ for inhibition $\left(P K A\right.$ protein kinase A, $P K C$ protein kinase $\mathrm{C}, P I P_{2}$ phosphatidylinositol-4,5-bisphosphate)

regulated closely by $\mathrm{Ca}^{2+}$ in the latter's physiological range (100-500 $\mathrm{nM})[100]$ and, therefore, $\mathrm{Ca}^{2+}$-elevating agonists, such as acetylcholine or histamine, increase KCNN4 open probability. KCNN4 activation hyperpolarizes the basolateral and-depending on the permeability of the paracellular pathway-also the luminal membrane of enterocytes, thereby supporting electrogenic transport, e.g. luminal $\mathrm{Cl}^{-}$secretion or $\mathrm{Na}^{+}$reabsorption (Fig. 1). KCNN4 is expressed abundantly in epithelial cells of colon [107] and of salivary glands [75, 95] and less in small intestine $[34,41]$. However, during cAMP- mediated intestinal $\mathrm{Cl}^{-}$secretion, $\mathrm{KCNN} 4$ activity is very low due to a reduction of intracellular $\mathrm{Ca}^{2+}$. The driving force for $\mathrm{Cl}^{-}$exit at the luminal side of the cell is maintained by a cAMP-stimulated basolateral $\mathrm{K}^{+}$conductance [106], which has been identified at the molecular level as KCNQ1 associated with its $\beta$-subunit KCNE3 [90]. Inhibition of KCNE3/KCNQ1 channel complex by the chromanol 293B or derivatives depolarizes the cell membrane, thereby diminishing the driving force for luminal $\mathrm{Cl}^{-}$exit via the cystic fibrosis transmembrane conductance regulator (CFTR) $\mathrm{Cl}^{-}$channel. Such a role for basolateral KCNE3/KCNQ1 channels in $\mathrm{Cl}^{-}$secretion has been observed in various $\mathrm{Cl}^{-}$ secreting epithelia such as colon [53, 63, 90], small intestine [108] and airways [30, 70]. In addition, KCNE3 might assemble with KCNQ1 in distal nephron segments of the kidney.

Besides the stabilization of membrane voltage during electrogenic transport, basolateral $\mathrm{K}^{+}$channels are engaged in maintenance of cell volume, which represents a continuous challenge for transporting cells. In colonic crypts, cell swelling induces activation of $\mathrm{KCNN} 4 \mathrm{~K}^{+}$ channels, probably via increases in intracellular $\mathrm{Ca}^{2+}$ activity. The enhanced $\mathrm{K}^{+}$conductance leads to an exit of $\mathrm{K}^{+}$as an osmolyte, stabilizes the membrane voltage and supports $\mathrm{Cl}^{-}$secretion. Together these mechanisms underlie the regulatory volume decrease [110]. $\mathrm{Na}^{+}$ coupled reabsorption of sugars and amino acids depolarizes the membrane of small intestinal enterocytes and is paralleled by osmotic water influx. Depolarization, changes in the metabolic state and cell swelling activate basolateral (and luminal) $\mathrm{K}^{+}$channels, which in turn repolarize the membrane voltage needed for ongoing transport and regulatory volume decrease [31, 68]. Similar mechanisms of $\mathrm{K}^{+}$channel activation have been described in renal proximal tubular cells which perform mass transport of solutes and water similar to small intestinal enterocytes. Reabsorption of glucose and phenylalanine has been shown to activate (probably via cell swelling [99]) basolateral $\mathrm{K}^{+}$channels in proximal tubular cells [11] and there is good evidence for an ATPregulated $\mathrm{K}^{+}$conductance that allows recycling of $\mathrm{K}^{+}$ taken up by $\mathrm{Na}^{+} / \mathrm{K}^{+}$-ATPase $[54,55,71,78]$ (Fig. 1A). The $\mathrm{pH}$-regulated and cell volume-sensitive $\mathrm{K}^{+}$channel KCNK5 (TASK2) is expressed strongly in renal proximal tubules. KCNK5 is - among others-a good candidate channel for activation by transport-associated changes in cell metabolism, cell volume and extracellular $\mathrm{pH}$ (possible activation by increase in basolateral $\mathrm{NaHCO}_{3}$ extrusion) $[6,76,77,86,109]$. The precise function and subcellular localization of renal KCNK5 channels, however, remains to be established.

Furthermore, inwardly rectifying ATP-sensitive $\mathrm{K}^{+}$ channels (members of the KCNJ family), cyclic nucleotide-regulated $\mathrm{K}^{+}$channels and maxi $\mathrm{K}^{+}$channels (KCNMA1 associated with $\beta$-subunits) have been described or proposed as basolateral $\mathrm{K}^{+}$channels in various epithelial tissues on the basis of immuno-localization 
studies and functional characteristics of native channels $[10,35,49,66,68,79]$.

\section{Luminal $\mathrm{K}^{+}$channels: repolarization, fine tuning of $\mathrm{K}^{+}$excretion and $\mathrm{K}^{+}$recycling}

In renal proximal tubules, and probably in the small intestine, luminal $\mathrm{K}^{+}$channels play an important role for restoring the driving force of $\mathrm{Na}^{+}$-coupled transport systems (amino acids, sugars), which depolarize the luminal membrane (Fig. 1A). Some of these luminal $\mathrm{K}^{+}$ channels are activated directly by the transport-associated depolarization (i.e. KCNE1/KCNQ1 and KCNA10 in renal proximal tubules $[98,116])$, others are regulated by mediators, second messenger pathways and cell volume $[36,37,93]$. Since the epithelia of small intestinal villi and renal proximal tubules have a low paracellular resistance [27], basolateral $\mathrm{K}^{+}$channels act in concert with luminal channels and hyperpolarize both basolateral and luminal membranes. However, the direction of the paracellular short circuit current differs, depending on luminal or basolateral $\mathrm{K}^{+}$channel activation [104].

In more "tight" epithelia, such as distal colon and renal collecting duct, the relative importance of luminal $\mathrm{K}^{+}$ channels for repolarization is enhanced compared with "proximal" epithelia: in the presence of a high paracellular resistance, activation of basolateral $\mathrm{K}^{+}$channels does not suffice to hyperpolarize the luminal membrane. Moreover, the luminal $\mathrm{K}^{+}$channel activity in "distal" epithelia directly affects the ionic composition of urine and faeces: i.e. activation of luminal $\mathrm{K}^{+}$channels during colonic $\mathrm{Cl}^{-}$secretion results in electroneutral $\mathrm{KCl}$ secretion; activation of basolateral $\mathrm{K}^{+}$channels, however, leads to electrogenic luminal $\mathrm{Cl}^{-}$exit followed by paracellular $\mathrm{Na}^{+}$flux $\left(\mathrm{NaCl}\right.$ secretion) $[32,52]$. Therefore, luminal $\mathrm{K}^{+}$ channel activity in the distal colon and renal collecting ducts is adjusted tightly according to body $\mathrm{K}^{+}$homeostasis. In the distal colon, luminal $\mathrm{K}^{+}$conductance is enhanced by the mineralocorticoid aldosterone and dietary $\mathrm{K}^{+}$intake $[64,88]$. Very recently, it has been shown in colonic mucosa, that luminal purinergic receptor stimulation regulates luminal $\mathrm{K}^{+}$channels, identified molecularly as maxi-K ${ }^{+}$channels (KCNMA1) [51, 59] (Fig. 1D).

In native collecting duct cells, at least two different types of luminal $\mathrm{K}^{+}$channels have been identified, smallconductance (25-35 pS) and large-conductance (80$140 \mathrm{pS}$ ) channels [111]. The abundance of the smallconductance channel is increased with a $\mathrm{K}^{+}$-rich diet, but not with a low- $\mathrm{Na}^{+}$diet $[26,80]$. The small-conductance $\mathrm{K}^{+}$channel is probably encoded by the KCNJ1 gene (ROMK) [38, 67], which is defective in antenatal Bartter syndrome type 2 [Online Mendelian Inheritance in Man (OMIM) database http://www.ncbi.nlm.nih.gov/omim/ classification No. 600359). The large-conductance $\mathrm{K}^{+}$ channel (maxi-K channel, KCNMA1) is activated by flow-induced membrane stretch and by rises in cytosolic
$\mathrm{Ca}^{2+}$. This might contribute to the increase in $\mathrm{K}^{+}$ excretion at high urinary flow rate $[74,111]$.

In $\mathrm{K}^{+}$-excreting epithelial cells, luminal $\mathrm{K}^{+}$channels underlie vectorial transport of $\mathrm{K}^{+}$across the epithelium. On the other hand, luminal and basolateral $\mathrm{K}^{+}$channels can also mediate $\mathrm{K}^{+}$recycling. For example, in renal thick ascending limb (TAL) cells, KCNJ1 (ROMK) plays a crucial role for $\mathrm{K}^{+}$recycling across the luminal membrane. This $\mathrm{K}^{+}$recycling is needed for $\mathrm{Na}^{+}$reabsorption via the $\mathrm{Na}^{+} 2 \mathrm{Cl}^{-} \mathrm{K}^{+}$cotransporter (NKCC2) (Fig. 1B). In patients suffering from $\mathrm{KCNJ} 1$ mutations, $\mathrm{Na}^{+}$reabsorption by the NKCC 2 is markedly diminished, resulting in a life-threatening salt wasting syndrome (antenatal Bartter syndrome type 2 ).

In the small intestine and renal proximal tubule, basolateral $\mathrm{K}^{+}$channels are coupled to $\mathrm{Na}^{+} / \mathrm{K}^{+}$ATPase activity. This allows $\mathrm{K}^{+}$to recycle, thus ensuring hyperpolarization, lowering of intracellular $\left[\mathrm{K}^{+}\right]$, ongoing $\mathrm{Na}^{+} /$ $\mathrm{K}^{+}$ATPase activity and reabsorption of $\mathrm{Na}^{+}$and $\mathrm{Na}^{+}$ coupled substrates [31, 71].

Gastric parietal cells secrete fluid containing $150 \mathrm{mM}$ $\mathrm{HCl}$. The acid-producing enzyme is a $\mathrm{P}_{2}$-type ATPase, which pumps $\mathrm{H}^{+}$into the lumen coupled to uptake of $\mathrm{K}^{+}$ $[23,24]$. Therefore, a continuous supply of luminal $\mathrm{K}^{+}$is required for sustained acid production by parietal cells (Fig. 1E). Almost 20 years ago, it was postulated that the $\mathrm{K}^{+}$recycling pathway is a $\mathrm{K}^{+}$conductance, but the molecular identity of the $\mathrm{K}^{+}$channel(s) remained unclear [113]. The observation of impaired gastric acid secretion paralleled by massive gastric hyperplasia (probably due to high gastrin levels) in KCNQ1 knockout mice indicated that KCNQ1 might be involved in acid secretion [58]. In fact, KCNQ1 co-assembles with KCNE2 to form a luminal $\mathrm{K}^{+}$channel in gastric parietal cells [14, 29]. Inhibition of KCNQ1 by the chromanol 293B almost completely inhibits acid secretion in mouse, rat and dog in vivo and in isolated rabbit gastric glands in vitro [29]. These pharmacological data and the gastric phenotype of KCNQ1 knockout mice suggest that KCNQ1 is required for $\mathrm{K}^{+}$recycling across the luminal membrane for sustained $\mathrm{H}^{+} / \mathrm{K}^{+}$ATPase activity. In addition to KCNQ1, $\mathrm{KCNJ} 10$ is located in the luminal membrane of parietal cells and probably acts together with KCNQ1 to recycle $\mathrm{K}^{+}[28]$.

\section{Conclusions}

$\mathrm{K}^{+}$channels fulfil a variety of different tasks in epithelial cells and are regulated precisely so as to adapt to cellular needs. In recent years we have gained greater insight into $\mathrm{K}^{+}$channel genetics and the functional properties of the channels in expression systems. Elucidation of the function of molecularly identified $\mathrm{K}^{+}$channels in native tissue, their subunit compositions and interactions with regulatory proteins and macromolecular complexes is needed for a better understanding of the physiological roles of epithelial $\mathrm{K}^{+}$channels and possible clinical implications. Specific pharmacological modulation of 
epithelial $\mathrm{K}^{+}$channels will offer new perspectives for the treatment of epithelia-linked diseases such as diarrhoea, peptic ulcer and metabolic disorders.

\section{References}

1. Aguilar-Bryan L, Nichols CG, Wechsler SW, Clement JP, Boyd AE, González G, Herrera-Sosa H, Nguy K, Bryan J, Nelson DA (1995) Cloning of the beta cell high-affinity sulfonylurea receptor: a regulator of insulin secretion. Science 268:423-426

2. Andelfinger G, Tapper AR, Welch RC, Vanoye CG, George AL Jr, Benson DW (2002) KCNJ2 mutation results in Andersen syndrome with sex-specific cardiac and skeletal muscle phenotypes. Am J Hum Genet 71:663-668

3. Anzai N, Izumida I, Inagaki N, Seino S, Kawahara K (1997) Expression of uKATP-1 (Kir6.1) in neonatal rat kidney proximal tubule. Jpn J Physiol 47 (Suppl 1):S10-S11

4. Arrighi I, Bloch-Faure M, Grahammer F, Bleich M, Warth R, Mengual R, Drici MD, Barhanin J, Meneton P (2001) Altered potassium balance and aldosterone secretion in a mouse model of human congenital long QT syndrome. Proc Natl Acad Sci USA 98:8792-8797

5. Ashmole I, Goodwin PA, Stanfield PR (2001) TASK-5, a novel member of the tandem pore $\mathrm{K}^{+}$channel family. Pflugers Arch 442:828-833

6. Beck JS, Hurst AM, Lapointe J-Y, Laprade R (1993) Regulation of basolateral $\mathrm{K}$ channels in proximal tubule studied during continuous microperfusion. Am J Physiol 264:F496-F501

7. Beesley AH, Qureshi IZ, Giesberts AN, Parker AJ, White SJ (1999) Expression of sulphonylurea receptor protein in mouse kidney. Pflugers Arch 438:1-7

8. Behrens R, Nolting A, Reimann F, Schwarz M, Waldschutz R, Pongs O (2000) hKCNMB3 and hKCNMB4, cloning and characterization of two members of the large-conductance calcium-activated potassium channel beta subunit family. FEBS Lett 474:99-106

9. Bleich M, Schlatter E, Greger R (1990) The luminal $\mathrm{K}^{+}$ channel of the thick ascending limb of Henle's loop. Pflugers Arch 415:449-460

10. Brochiero E, Wallendorf B, Gagnon D, Laprade R, Lapointe JY (2002) Cloning of rabbit Kir6.1, SUR2A, and SUR2B: possible candidates for a renal $\mathrm{K}_{\mathrm{ATP}}$ channel. Am J Physiol 282:F289-F300

11. Cemerikic D, Sackin H (1993) Substrate activation of mechanosensitive, whole cell currents in renal proximal tubule. Am J Physiol 264:F697-F714

12. Chavez RA, Gray AT, Zhao BB, Kindler CH, Mazurek MJ, Mehta Y, Forsayeth JR, Yost CS (1999) TWIK-2, a new weak inward rectifying member of the tandem pore domain potassium channel family. J Biol Chem 274:7887-7892

13. Cluzeaud F, Reyes R, Escoubet B, Fay M, Lazdunski M, Bonvalet JP, Lesage F, Farman N (1998) Expression of TWIK-1, a novel weakly inward rectifying potassium channel in rat kidney. Am J Physiol 275:C1602-C1609

14. Dedek K, Waldegger S (2001) Colocalization of KCNQ1/ KCNE channel subunits in the mouse gastrointestinal tract. Pflugers Arch 442:896-902

15. Derst C, Hirsch JR, Preisig-Muller R, Wischmeyer E, Karschin A, Doring F, Thomzig A, Veh RW, Schlatter E, Kummer W, Daut J (2001) Cellular localization of the potassium channel Kir7.1 in guinea pig and human kidney. Kidney Int 59:2197-2205

16. Derst C, Karschin C, Wischmeyer E, Hirsch JR, PreisigMuller R, Rajan S, Engel H, Grzeschik K, Daut J, Karschin A (2001) Genetic and functional linkage of Kir5.1 and Kir2.1 channel subunits. FEBS Lett 491:305-311
17. Devor DC, Frizzell RA (1998) Modulation of $\mathrm{K}^{+}$channels by arachidonic acid in T84 cells. I. Inhibition of the $\mathrm{Ca}^{2+}$ dependent $\mathrm{K}^{+}$channel. Am J Physiol 274:C138-C148

18. Devor DC, Singh AK, Frizzell RA, Bridges RJ (1996) Modulation of $\mathrm{Cl}^{-}$secretion by benzimidazolones. I. Direct activation of a $\mathrm{Ca}^{2+}$-dependent $\mathrm{K}^{+}$channel. Am J Physiol 271:L775-L784

19. Dong K, Xu J, Vanoye CG, Welch R, MacGregor GG, Giebisch G, Hebert SC (2001) An amino acid triplet in the $\mathrm{NH} 2$ terminus of rat ROMK1 determines interaction with SUR2B. J Biol Chem 276:44347-44353

20. Embark HM, Böhmer C, Vallon V, Luft F, Lang F (2003) Regulation of KCNE1-dependent $\mathrm{K}^{+}$current by the serum and glucocorticoid-inducible kinase (SGK) isoforms. Pflugers Arch 445:601-606

21. Fanger CM, Ghanshani S, Logsdon NJ, Rauer H, Kalman K, Zhou J, Beckingham K, Chandy KG, Cahalan MD, Aiyar J (1999) Calmodulin mediates calcium-dependent activation of the intermediate conductance $\mathrm{KCa}$ channel, IKCa1. J Biol Chem 274:5746-5754

22. Fink M, Duprat F, Lesage F, Reyes R, Romey G, Heurteaux C, Lazdunski M (1996) Cloning, functional expression and brain localization of a novel unconventional outward rectifier $\mathrm{K}^{+}$ channel. EMBO J 15:6854-6862

23. Forte JG, Forte GM, Saltman P (1967) $\mathrm{K}^{+}$-stimulated phosphatase of microsomes from gastric mucosa. J Cell Physiol 69:293-304

24. Forte JG, Ganser A, Beesley R, Forte TM (1975) Unique enzymes of purified microsomes from pig fundic mucosa. $\mathrm{K}^{+}$stimulated adenosine triphosphatase and $\mathrm{K}^{+}$-stimulated pNPPase. Gastroenterology 69:175-189

25. Friedmann I, Fraser GR, Froggatt P (1966) Pathology of the ear in the cardio-auditory syndrome of Jervell and LangeNielsen (recessive deafness with electrocardiographic abnormalities). J Laryngol 80:451-470

26. Frindt G, Palmer LG (1989) Low-conductance K channels in apical membrane of rat cortical collecting tubule. Am J Physiol 256:F143-F151

27. Frömter E, Diamond J (1972) Route of passive ion permeation in epithelia. Nature 235:9-13

28. Fujita A, Horio Y, Higashi K, Mouri T, Hata F, Takeguchi N, Kurachi Y (2002) Specific localization of an inwardly rectifying $\mathrm{K}^{+}$channel, Kir4.1, at the apical membrane of rat gastric parietal cells; its possible involvement in $\mathrm{K}^{+}$recycling for the $\mathrm{H}^{+}-\mathrm{K}^{+}$-pump. J Physiol (Lond) 540:85-92

29. Grahammer F, Herling AW, Lang HJ, Schmitt-Gräff A Wittekindt $\mathrm{OH}$, Nitschke R, Bleich M, Barhanin J, Warth R (2001) The cardiac $\mathrm{K}^{+}$channel KCNQ1 is essential for gastric acid secretion. Gastroenterology 120:1363-1371

30. Grahammer F, Warth R, Barhanin J, Bleich M, Hug MJ (2001) The small conductance $\mathrm{K}^{+}$channel, KCNQ1. Expression, function, and subunit composition in murine trachea. J Biol Chem 246:42268-42275

31. Grasset E, Gunter-Smith P, Schultz SG (1983) Effects of Nacoupled alanine transport on intracellular $\mathrm{K}$ activities and the $\mathrm{K}$ conductance of the basolateral membranes of Necturus small intestine. J Membr Biol 71:89-94

32. Greger R, Bleich M, Leipziger J, Ecke D, Mall M, Kunzelmann K (1997) Regulation of ion transport in colonic crypts. News Physiol Sci 12:62-66

33. Gu W, Schlichthorl G, Hirsch JR, Engels H, Karschin C, Karschin A, Derst C, Steinlein OK, Daut J (2002) Expression pattern and functional characteristics of two novel splice variants of the two-pore-domain potassium channel TREK-2. J Physiol (Lond) 539:657-668

34. Hamilton KL, Meads L, Butt AG (1999) 1-EBIO stimulates $\mathrm{Cl}^{-}$secretion by activating a basolateral $\mathrm{K}^{+}$channel in the mouse jejunum. Pflugers Arch 439:158-166

35. Hirsch J, Schlatter E (1995) $\mathrm{K}^{+}$channels in the basolateral membrane of rat cortical collecting duct are regulated by a cGMP-dependent protein kinase. Pflugers Arch 429:338-344 
36. Hirsch JR, Meyer M, Magert HJ, Forssmann WG, Mollerup S, Herter P, Weber G, Cermak R, Ankorina-Stark I, Schlatter E, Kruhoffer M (1999) cGMP-dependent and -independent inhibition of $\mathrm{a} \mathrm{K}^{+}$conductance by natriuretic peptides: molecular and functional studies in human proximal tubule cells. J Am Soc Nephrol 10:472-480

37. Hirsch JR, Weber G, Kleta I, Schlatter E (1999) A novel cGMP-regulated $\mathrm{K}^{+}$channel in immortalized human kidney epitheliall cells (IHKE-1). J Physiol (Lond) 519:645-655

38. Ho K, Nichols CG, Lederer WJ, Lytton J, Vassilev PM, Kanazirska MV, Hebert SC (1993) Cloning and expression of an inwardly rectifying ATP-regulated potassium channel. Nature 362:31-38

39. Inagaki $\mathrm{N}$, Gonoi $\mathrm{T}$, Clement $\mathrm{JP}$, Namba $\mathrm{N}$, Inazawa $\mathrm{J}$, Gonzalez G, Aguilar-Bryan L, Seino S, Bryan J (1995) Reconstitution of IKATP: an inward rectifier subunit plus the sulfonylurea receptor. Science 270:1166-1170

40. Ishii TM, Silvia C, Hirschberg B, Bond CT, Adelman JP, Maylie J (1997) A human intermediate conductance calciumactivated potassium channel. Proc Natl Acad Sci USA 94:11651-11656

41. Jensen BS, Strobaek D, Christophersen P, Jorgensen TD, Hansen C, Silahtaroglu A, Olesen SP, Ahring PK (1998) Characterization of the cloned human intermediate-conductance $\mathrm{Ca}^{2+}$-activated $\mathrm{K}^{+}$channel. Am J Physiol 275:C848$\mathrm{C} 856$

42. Joiner WJ, Wang L-Y, Tang MD, Kaczmarek LK (1997) hSK4, a member of a novel subfamily of calcium-activated potassium channels. Proc Natl Acad Sci USA 94:1101311018

43. Khanna R, Chang MC, Joiner WJ, Kaczmarek LK, Schlichter LC (1999) hSK4/hIK1, a calmodulin-binding KCa channel in human $\mathrm{T}$ lymphocytes. Roles in proliferation and volume regulation. J Biol Chem 274:14838-14849

44. Kim D, Gnatenco C (2001) Task-5, a new member of the tandem-pore $\mathrm{K}^{+}$channel family. Biochem Biophys Res Commun 284:923-930

45. Kim SJ, Greger R (1999) Voltage-dependent, slowly activating $\mathrm{K}^{+}$current $\left(\mathrm{I}_{\mathrm{Ks}}\right)$ and its augmentation by carbachol in rat pancreatic acini. Pflugers Arch 438:604-611

46. Kim SJ, Kim JK, Pavenstädt H, Greger R, Hug MJ, Bleich M (2001) Regulation of slowly activating potassium current $\left(\mathrm{I}_{\mathrm{Ks}}\right)$ by secretin in rat pancreatic acinar cells. J Physiol (Lond) 535:349-358

47. Kim Y, Bang H, Kim D (2000) TASK-3, a new member of the tandem pore $\mathrm{K}^{+}$channel family. J Biol Chem 275:9340-9347

48. Kim Y, Gnatenco C, Bang H, Kim D (2001) Localization of TREK-2 $\mathrm{K}^{+}$channel domains that regulate channel kinetics and sensitivity to pressure, fatty acids and pHi. Pflugers Arch 442:952-960

49. Klaerke DA, Wiener H, Zeuthen T, Jorgensen PL (1993) $\mathrm{Ca}^{2+}$ activation and $\mathrm{pH}$ dependence of a maxi- $\mathrm{K}^{+}$channels from rabbit distal colon epithelium. J Membr Biol 136:9-21

50. Konstas AA, Dabrowski M, Korbmacher C, Tucker SJ (2002) Intrinsic sensitivity of Kir1.1 (ROMK) to glibenclamide in the absence of SUR2B. Implications for the identity of the renal ATP-regulated secretory $\mathrm{K}^{+}$channel. J Biol Chem 277:2134621351

51. Köttgen M, Löffler T, Jacobi C, Nitschke R, Pavenstädt H, Schreiber R, Frische S, Nielsen S, Leipziger J (2003) P2Y6 receptor mediates colonic $\mathrm{NaCl}$ secretion via differential activation of cAMP-mediated transport. $\mathrm{J}$ Clin Invest 111:371-379

52. Kunzelmann K, Mall M (2002) Electrolyte transport in the mammalian colon: mechanisms and implications for disease. Physiol Rev 82:245-289

53. Kunzelmann K, Hübner M, Schreiber R, Levy-Holzman R, Garty H, Bleich M, Warth R, Slavik M, von Hahn T, Greger R (2001) Cloning and function of the rat colonic epithelial $\mathrm{K}^{+}$ channel KvLQT1. J Membr Biol 179:155-164

54. Lang F, Rehwald W (1992) Potassium channels in renal epithelial transport regulation. Physiol Rev 72:1-32
55. Lang F, Messner G, Rehwald W (1986) Electrophysiology of sodium-coupled transport in proximal renal tubules. Am J Physiol 250:F953-F962

56. Lee E, Gerlach U, Uhm DY, Kim J (2002) Inhibitory effect of somatostatin on secretin-induced augmentation of the slowly activating $\mathrm{K}^{+}$current (IKs) in the rat pancreatic acinar cell. Pflugers Arch 443:405-410

57. Lee JE, Kim JH, Choi SJ, Han TH, Uhm DY, Kim SJ (2002) Inhibitory effects of $\mathrm{PGE}_{2}$ on $\mathrm{K}^{+}$currents and $\mathrm{Ca}^{2+}$ oscillations in rat pancreatic acinar cells. Pflugers Arch 444:619-626

58. Lee MP, Ravenel JD, Hu RJ, Lustig LR, Tomaselli G, Berger RD, Brandenburg SA, Litzi TJ, Bunton TE, Limb C, Francis $\mathrm{H}$, Gorelikow M, Gu H, Washington K, Argani P, Goldenring JR, Coffey RJ, Feinberg AP (2000) Targeted disruption of the Kvlqt1 gene causes deafness and gastric hyperplasia in mice. J Clin Invest 106:1447-1455

59. Leipziger J, Matos J, Sausbier M, Ruth P (2003) Abolished colonic $\mathrm{K}^{+}$secretion in Maxi $\mathrm{K}^{+}$channel knock-out mice (abstract). Pflugers Arch (In press)

60. Lesage F, Guillemare E, Fink M, Duprat F, Lazdunski M, Romey G, Barhanin J (1996) TWIK-1, a ubiquitous human weakly inward rectifying $\mathrm{K}^{+}$channel with a novel structure. EMBO J 15:1004-1011

61. Lesage F, Lauritzen I, Duprat F, Reyes R, Fink M, Heurteaux C, Lazdunski M (1997) The structure, function and distribution of the mouse TWIK-1 K ${ }^{+}$channel. FEBS Letters 402:2832

62. Liu Y, McKenna E, Figueroa DJ, Blevins R, Austin CP, Bennett PB, Swanson R (2000) The human inward rectifier $\mathrm{K}^{+}$ channel subunit kir5.1 (KCNJ16) maps to chromosome 17q25 and is expressed in kidney and pancreas. Cytogenet Cell Genet 90:60-63

63. Lohrmann E, Burhoff I, Nitschke RB, Lang HJ, Mania D, Englert HC, Hropot M, Warth R, Rohm W, Bleich M, Greger $\mathrm{R}$ (1995) A new class of inhibitors of cAMP-mediated $\mathrm{Cl}^{-}$ secretion in rabbit colon, acting by the reduction of cAMPactivated $\mathrm{K}^{+}$conductance. Pflugers Arch 429:517-530

64. Lomax RB, McNicholas CM, Lombes M, Sandle GI (1994) Aldosterone-induced apical $\mathrm{Na}^{+}$and $\mathrm{K}^{+}$conductances are located predominantly in surface cells in rat distal colon. Am J Physiol 266:G71-G82

65. Lomax RB, Warhurst G, Sandle GI (1996) Characteristics of two basolateral potassium channel populations in human colonic crypts. Gut 38:243-247

66. Lourdel S, Paulais M, Cluzeaud F, Bens M, Tanemoto M, Kurachi Y, Vandewalle A, Teulon J (2002) An inward rectifier $\mathrm{K}^{+}$channel at the basolateral membrane of the mouse distal convoluted tubule: similarities with Kir4-Kir5.1 heteromeric channels. J Physiol (Lond) 538:391-404

67. Lu M, Wang T, Yan Q, Yang X, Dong K, Knepper MA, Wang W, Giebisch G, Shull GE, Hebert SC (2002) Absence of small-conductance $\mathrm{K}^{+}$channel (SK) activity in apical membranes of thick ascending limb and cortical collecting duct in ROMK (Bartter's) knockout mice. J Biol Chem 277:3788137887

68. MacLeod RJ, Hamilton JR (1999) Increases in intracellular pH and $\mathrm{Ca}^{2+}$ are essential for $\mathrm{K}^{+}$channel activation after modest 'physiological' swelling in villus epithelial cells. J Membr Biol 172:47-58

69. MacVinish J, Keogh J, Cuthbert W (2001) EBIO, an agent causing maintained epithelial chloride secretion by co-ordinate actions at both apical and basolateral membranes. Pflugers Arch 443 (Suppl 1):S127-S131

70. Mall M, Wissner A, Schreiber R, Kuehr J, Seydewitz HH, Brandis M, Greger R, Kunzelmann K (2000) Role of KVLQT1 in cyclic adenosine monophosphate-mediated $\mathrm{Cl}^{-}$secretion in human airway epithelia. Am J Respir Cell Mol Biol 23:283289

71. Mauerer UR, Boulpaep EL, Segal AS (1998) Regulation of an inwardly rectifying ATP-sensitive $\mathrm{K}^{+}$channel in the basolateral membrane of renal proximal tubule. J Gen Physiol 111:161-180 
72. Medhurst AD, Rennie G, Chapman CG, Meadows H, Duckworth MD, Kelsell RE, Gloger II, Pangalos MN (2001) Distribution analysis of human two pore domain potassium channels in tissues of the central nervous system and periphery. Brain Res Mol Brain Res 86:101-114

73. Morton MJ, O'Connell AD, Sivaprasadarao A, Hunter M (2003) Determinants of $\mathrm{pH}$ sensing in the two-pore domain $\mathrm{K}^{+}$ channels TASK-1 and -2. Pflugers Arch 445:577-583

74. Muto S (2001) Potassium transport in the mammalian collecting duct. Physiol Rev 81:85-116

75. Nehrke K, Quinn CC, Begenisich T (2003) Molecular identification of the $\mathrm{Ca}^{2+}$-activated $\mathrm{K}^{+}$channels in parotid acinar cells. Am J Physiol 284:C535-C546

76. Niemeyer MI, Cid LP, Barros LF, Sepulveda FV (2001) Modulation of the two-pore domain acid-sensitive $\mathrm{K}^{+}$channel TASK-2 (KCNK5) by changes in cell volume. J Biol Chem 276:43166-43174

77. Niemeyer MI, Cid LP, Sepulveda FV (2001) $\mathrm{K}^{+}$conductance activated during regulatory volume decrease. The channels in Ehrlich cells and their possible molecular counterpart. Comp Biochem Physiol A Mol Integr Physiol 130:565-575

78. Noulin JF, Brochiero E, Lapointe JY, Laprade R (1999) Two types of $\mathrm{K}^{+}$channels at the basolateral membrane of proximal tubule: inhibitory effect of taurine. Am J Physiol 277:F290F297

79. Olsen O, Liu H, Wade JB, Merot J, Welling PA (2002) Basolateral membrane expression of the Kir 2.3 channel is coordinated by PDZ interaction with Lin-7/CASK complex. Am J Physiol 282:C183-C195

80. Palmer LG, Antonian L, Frindt G (1994) Regulation of apical $\mathrm{K}$ and $\mathrm{Na}$ channels and $\mathrm{Na} / \mathrm{K}$ pumps in rat cortical collecting tubule by dietary K. J Gen Physiol 104:693-710

81. Partiseti M, Collura V, Agnel M, Culouscou JM, Graham D (1998) Cloning and characterization of a novel human inwardly rectifying potassium channel predominantly expressed in small intestine. FEBS Lett 434:171-176

82. Pountney DJ, Gulkarov I, Vega-Saenz dM, Holmes D, Saganich M, Rudy B, Artman M, Coetzee WA (1999) Identification and cloning of TWIK-originated similarity sequence (TOSS): a novel human 2-pore $\mathrm{K}^{+}$channel principal subunit. FEBS Lett 450:191-196

83. Pountney DJ, Gulkarov I, Vega-Saenz dM, Holmes D, Saganich M, Rudy B, Artman M, Coetzee WA (1999) Identification and cloning of TWIK-originated similarity sequence (TOSS): a novel human 2-pore K channel principal subunit. FEBS Lett 450:191-196

84. Preisig-Muller R, Schlichthorl G, Goerge T, Heinen S, Bruggemann A, Rajan S, Derst C, Veh RW, Daut J (2002) Heteromerization of Kir2.x potassium channels contributes to the phenotype of Andersen's syndrome. Proc Natl Acad Sci USA 99:7774-7779

85. Rajan S, Wischmeyer E, Xin LG, Preisig-Muller R, Daut J, Karschin A, Derst C (2000) TASK-3, a novel tandem pore domain acid-sensitive $\mathrm{K}^{+}$channel. An extracellular histidine as $\mathrm{pH}$ sensor. J Biol Chem 275:16650-16657

86. Reyes R, Duprat F, Lesage F, Fink M, Salinas M, Farman N, Lazdunski M (1998) Cloning and expression of a novel $\mathrm{pH}$ sensitive two pore domain $\mathrm{K}^{+}$channel from human kidney. $\mathrm{J}$ Biol Chem 273:30863-30869

87. Salinas M, Reyes R, Lesage F, Fosset M, Heurteaux C, Romey G, Lazdunski M (1999) Cloning of a new mouse two-P domain channel subunit and a human homologue with a unique pore structure. J Biol Chem 274:11751-11760

88. Sandle GI, Butterfield I (1999) Potassium secretion in rat distal colon during dietary potassium loading: role of $\mathrm{pH}$ regulated apical potassium channels. Gut 44:40-46

89. Schreiber R, Murle B, Sun J, Kunzelmann K (2002) Electrolyte transport in the mouse trachea: no evidence for a contribution of luminal $\mathrm{K}^{+}$conductance. $\mathrm{J}$ Membr Biol 189:143-151
90. Schroeder BC, Waldegger S, Fehr S, Bleich M, Warth R, Greger R, Jentsch TJ (2000) A constitutively open potassium channel formed by KCNQ1 and KCNE3. Nature 403:196-199

91. Schultheiss G, Ribeiro R, Diener M (2001) Fatty acids inhibit anion secretion in rat colon: apical and basolateral action sites. Pflugers Arch 442:603-613

92. Seghers V, Nakazaki M, DeMayo F, Aguilar-Bryan L, Bryan J (2000) Sur1 knockout mice. A model for $\mathrm{K}_{\mathrm{ATP}}$ channelindependent regulation of insulin secretion. J Biol Chem 275:9270-9277

93. Sindice A, Basoglu C, Cerci A, Hirsch JR, Potthast R, Kuhn M, Ghanekar Y, Visweswariah SS, Schlatter E (2002) Guanylin, uroguanylin, and heat-stable euterotoxin activate guanylate cyclase $\mathrm{C}$ and/or a pertussis toxin-sensitive $\mathrm{G}$ protein in human proximal tubule cells. J Biol Chem 277:17758-17764

94. Sorensen JB, Nielsen MS, Gudme CN, Larsen EH, Nielsen R (2001) Maxi $\mathrm{K}^{+}$channels co-localised with CFTR in the apical membrane of an exocrine gland acinus: possible involvement in secretion. Pflugers Arch 442:1-11

95. Takahata T, Hayashi M, Ishikawa T (2002) SK4/IK1-like channels mediate tetraethylammonium insensitive, $\mathrm{Ca}^{2+}$-activated $\mathrm{K}^{+}$currents in bovine parotid acinar cells. Am J Physiol 284:C127-C144

96. Tucker SJ, Imbrici P, Salvatore L, D'Adamo MC, Pessia M (2000) $\mathrm{pH}$ dependence of the inwardly rectifying potassium channel, Kir5.1, and localization in renal tubular epithelia. J Biol Chem 275:16404-16407

97. Tyson J, Tranebjaerg L, Bellman S, Wren C, Taylor JF, Bathen J, Aslaksen B, Sorland SJ, Lund O, Malcolm S, Pembrey M, Bhattacharya S, Bitner-Glindzicz M (1997) IsK and KvLQT1: mutation in either of the two subunits of the slow component of the delayed rectifier potassium channel can cause Jervell and Lange-Nielsen syndrome. Hum Mol Genet 6:2179-2185

98. Vallon V, Grahammer F, Richter K, Bleich M, Lang F, Barhanin J, Völkl H, Warth R (2001) Role of KCNE1dependent $\mathrm{K}^{+}$fluxes in mouse proximal tubule. J Am Soc Nephrol 12:2003-2011

99. Völkl H, Lang F (1988) Ionic requirement for regulatory cell volume decrease in renal straight proximal tubules. Pflugers Arch 412:1-6

100. Von Hahn T, Thiele I, Zingaro L, Hamm K, Garcia Alzamora M, Köttgen M, Bleich M, Warth R (2001) Characterisation of the rat SK4/IK1 K+ channel. Cell Physiol Biochem 11:219230

101. Wang Q, Curran ME, Splawski I, Burn TC, Millholland JM, VanRaay TJ, Shen J, Timothy KW, Vincent GM, de Jager T, Schwartz PJ, Toubin JA, Moss AJ, Atkinson DL, Landes GM, Connors TD, Keating MT (1996) Positional cloning of a novel potassium channel gene: KVLQT1 mutations cause cardiac arrhythmias. Nature Genet 12:17-23

102. Wang W, White S, Geibel J, Giebisch G (1990) A potassium channel in the apical membrane of rabbit thick ascending limb of Henle's loop. Am J Physiol 258:F244-F253

103. Warth R, Barhanin J (2002) The multifaceted phenotype of the knockout mouse for the KCNE1 potassium channel gene. Am J Physiol 282:R639-R648

104. Warth R, Barhanin J (2003) Function of $\mathrm{K}^{+}$channels in the intestinal epithelium. J Membr Biol (In press)

105. Warth R, Bleich M (2000) $\mathrm{K}^{+}$channels and colonic function. Rev Physiol Biochem Pharmacol 140:1-62

106. Warth R, Riedemann N, Bleich M, Van Driessche W, Busch AE, Greger R (1996) The cAMP-regulated and 293B inhibited $\mathrm{K}^{+}$conductance of rat colonic crypt base cells. Pflugers Arch 432:81-88

107. Warth R, Hamm K, Bleich M, Kunzelmann K, von Hahn T, Schreiber R, Ullrich E, Mengel M, Trautmann N, Kindle P, Schwab A, Greger R (1999) Molecular and functional characterisation of the small $\mathrm{Ca}^{2+}$-regulated $\mathrm{K}^{+}$channel (rSK4) of colonic crypts. Pflugers Arch 438:437-444 
108. Warth R, Garcia AM, Kim K, Zdebik A, Nitschke R, Bleich M, Gerlach U, Barhanin J, Kim J (2002) The role of KCNQ1/ $\mathrm{KCNE} 1 \mathrm{~K}^{+}$channels in intestine and pancreas: lessons from the KCNE1 knockout mouse. Pflugers Arch 443:822-828

109. Warth R, Tauc M, Poujeol P, Guy N, Barhanin J (2002) TASK2 $\mathrm{K}^{+}$channel knockout mice suffer from renal salt and water loss (abstract). Pflugers Arch 443:S171

110. Weyand B, Warth R, Bleich M, Greger R (1998) Hypertonic cell shrinkage reduces the $\mathrm{K}^{+}$conductance in rat colonic crypt cells. Pflugers Arch 436:227-232

111. Woda CB, Bragin A, Kleyman TR, Satlin LM (2001) Flowdependent $\mathrm{K}^{+}$secretion in the cortical collecting duct is mediated by a maxi-K channel. Am J Physiol 280:F786-F793

112. Wolf K, Castrop H, Riegger GA, Kurtz A, Kramer BK (2001) Differential gene regulation of renal salt entry pathways by salt load in the distal nephron of the rat. Pflugers Arch 442:498-504
113. Wolosin JM, Forte JG (1984) Stimulation of oxyntic cell triggers $\mathrm{K}^{+}$and $\mathrm{Cl}^{-}$conductances in apical $\mathrm{H}^{+}-\mathrm{K}^{+}$-ATPase membrane. Am J Physiol 246:C537-C545

114. Xu JZ, Hall AE, Peterson LN, Bienkowski MJ, Eessalu TE, Hebert SC (1997) Localization of the ROMK protein on apical membranes of rat kidney nephron segments. Am J Physiol 273:F739-F748

115. Yao X, Segal AS, Welling $\mathrm{P}$, Zhang $\mathrm{X}$, McNicholas $\mathrm{CM}$, Engel D, Boulpaep EL, Desir GV (1995) Primary structure and functional expression of a cGMP-gated potassium channel. Proc Natl Acad Sci USA 92:11711-11715

116. Yao X, Tian S, Chan HY, Biemesderfer D, Desir GV (2002) Expression of KCNA10, a voltage-gated $\mathrm{K}^{+}$channel, in glomerular endothelium and at the apical membrane of the renal proximal tubule. J Am Soc Nephrol 13:2831-2839 